\title{
Elliot Smith Memorial
}

$\mathrm{O}^{\mathrm{N}}$ Tuesday, May 3, in the Thane Library of the Faculty of Medical Sciences, University College, London, a bust in bronze of the late Sir Grafton Elliot Smith, professor of anatomy in the College from 1919 until 1936, was unveiled by Prof. J. T. Wilson and presented by him on tehalf of the sub. scribers to the chairman of the College Committee (the Right Hon. Viscount Sankey of Moreton). Prof. J. P. Hill reported on behalf of the Committee that the subscribers to the Fund included old friends, colleagues and pupils of Elliot Smith from all the continents, and most of the countries of the world. The execution of the memorial was entrusted to $\mathrm{Mr}$. A. H. Gerrard of the Slade School, and the bust is a striking portrayal of a man of vigorous personality and great intellectual capacity.

In making the presentation, Prof. Wilson, in a short speech of singular charm and warmth of feeling, remarked that Elliot Smith's best memorial is not material but spiritual and is to be found in the impressive record of his lifelong activity and in his influence on innumerable people besides his pupils, colleagues and friends. The qualities that his friends have recognized have been an extraordinarily penetrating vision and a capacity for interpretation, together with a striking vigour and clarity of exposition. Prof. Wilson made mention of the very varied character of Elliot Smith's career as an anatomist, first in Sydney, then in Cambridge, followed by Cairo, Manchester and finally London, and of how all these manifold experiences influenced the trends of his remarkable activities. He recalled that some forty-five years ago, Elliot Smith had been his pupil in the University of Sydney and afterwards his demonstrator, and speaking as the representative of his Alma Mater, he further recalled with pleasure that he had had the honour of recom. mending him for one of his first distinctions, the Gold Medal awarded for his thesis for the doctorate.

Lord Sankey, in accepting the bust on behalf of the College, said it was a remarkable memorial to a remarlable man and yet another treasure to the gallery of great and distinguished men who by their life and learning have contributed to the prestige of University College.

The Provost of the College, Sir Allen Mawer, in thanking Prof. Wilson and the subscribers, spoke of the part played by Elliot Smith in the negotiations with the Rockefeller Foundation which resulted in the munificent benefaction through which it was possible to build and equip the existing Department of Anatomy, and of his influence in promoting the close association which exists between the College and the universities of the Dominions and more particularly of Australia.

\section{Immunological Reactions of the Filterable Viruses}

$\mathrm{O}^{\mathrm{N}}$ $\mathrm{NE}$ of the greatest services which a group of investigators can give to the larger scientific public is the compilation of a sound and detailed résumé of their own particular field of research. F. M. Burnet, E. V. Keogh and Dora Lush have done this for the immunological reactions of the filterable viruses (Aus. J. Exp. Biol. and Med. Sci., 15 , Pt. 3 (supplement), pp. 231-368; 1937 : also published separately, price 10s. 0d., from the Librarian, Univ. of Adelaide; South Australia, or Messrs. H. K. Lewis and Co., Ltd., 136 Gower Street, London, W.C.1). The specialist contribution of these workers lies mainly in their quantitative study of the immunity reactions of numerous animal viruses, using a method which produces discrete pock marks upon the chorioallantoic membrane of a developing egg. Their present monograph contains a short reforence to the serology of plant viruses, but is otherwise devoted in detail to those which attack bacteria and mammalian animals. Chapter I contains a useful comparison of animal viruses with bacteriophages. The latter can be regarded as virus diseases of bacteria, and have particle-sizes commensurate with the small size of their hosts. They range from 10 to $65 \mathrm{~m} \mu$ in diameter, where animal viruses vary between 10 and $300 \mathrm{~m} \mu$. Both are composed mainly of nucleoprotein, with traces of ether-extractable substances and salts, whilst carbohydrates are lost during washing.

The section describing the immunology of bacteriophage is, of necessity, more general than that setting forth the comparable reactions of animal viruses. Specificity of bacteriophage inactivation by immune sera, differences in antigenicity among bacteriophages, and the antigenicity of inactivated phage, are some of the main lines of discussion, whilst the details of typical phage-antiserum reactions are given at considerable length.

It is possible to be much more specific in the sections which deal with the immunology of animal viruses. The causal agents of influenza, cow-pox (vaccinia), louping-ill, rift valley fever, equine encephalomyelitis, Newcastle disease, infectious laryngotracheitis and myxomatosis, are each given a particular chapter, wherein their immunology is adequately portrayed. Chapters upon virus immunity from a biological point of view, on the site of formation of virus antibodies, on the principles of active immunization against virus infections, and on modern views upon the antigen-antibody reaction, minister to the more general reader in search of biological background.

Considerable lists of references to the literature are given, and if the Australian investigations are emphasized somewhat, workers in the northern hemisphere can only be grateful for their concomitant availability, and be glad of such fundamental contributions. It would indeed be difficult to over-emphasize the value of such monographs as the one under review; it serves to nullify any incipient bewilderment at the increasing volume of modern knowledge in its particular sphere. 